\title{
The Book and Film Versions of Chetan Bhagat's Five Point Someone: A Cultural Study
}

\author{
Bemi. C. M \\ Assistant Professor, Department of English, Loyola College, Chennai, India
}

\begin{abstract}
Cultural Institutions are elements within a culture or subculture that are perceived to be important to, or traditionally valued among its members for their own identity. Examples of cultural institutions in modern western society are museums, churches, schools, work and the print media. Experts commonly name the following five cultural institutions as needed (at least in some way) in any society in order to survive: education, economic system, government, family, and religion. This paper examines the cultural institutions in Indian society which prevent the growth of the youngsters. The cultural institutions dealt in this paper are family, education and marriage. Parents themselves make choices for their children's higher education. They fail to consider their children's interest. They pressurize their children into a crazy race for more marks, a race which has never benefited anyone. The modern trend among people is to make their daughter a doctor, and son an engineer, influenced by the society.
\end{abstract}

Keywords-Education, Institution, Marriage, Parents, Youth.

A Culture is a system of shared beliefs, values, customs, behaviours, and artifacts that the members of society use to cope with their world and with one another, and that are transmitted from generation to generation through learning. Culture is made up of the common things that members of a community learn from family, friends, media, literature, and even strangers.

According to the article "Culture of India" in Wikipedia, the culture of India refers to the religions, beliefs, customs, traditions, languages, ceremonies, arts, values and the way of life in India and its people. India's languages, religions, dance, music, architecture, food and customs differ from place to place within the country. Its culture is often labeled as an amalgamation of these diverse sub-cultures spread all over the Indian subcontinent and traditions that are several millennia old. It has been rightly said that:

Culture is the name for what people are interested in, their thoughts, their models, the books they read and the speeches they hear, their table-talk, gossip, controversies, historical sense and scientific training, the values they appreciate, the quality of life they admire. All communities have a culture. It is the climate of their civilization. (Lippmann "What is Culture?")

Cultural institution means a public or nonprofit institution within the state which engages in the cultural, intellectual, scientific, environmental, educational or artistic enrichment of the people of the state. It includes, without limitation, aquaria, botanical societies, historical societies, land conservation organizations, libraries, museums, performing arts associations or societies, scientific societies, wildlife conservation organizations and zoological societies. Cultural institution does not mean any school or any institution primarily engaged in religious or sectarian activities.

In Indian society, there are many cultural institutions which detriment to the growth of the young generation. It is often said that the Indian culture and heritage is so powerful that it has acted like a strong backbone and has made Indians stand tall through tough times. However, the generation of today, does not conform to customs and traditions any more. They believe that cultural values are very rigid and highly orthodox and they hypocritically stop them from moving forward. Gradually one can see the generation of today shedding layers of our ethnic values. There are many unanswered questions raised on formalities and ritual ceremonies followed during festivals, marriages and several other social events.

Educational institutions in India are also the products of the society's cultural mores. Students are pressurized to learn the answers by heart and reproduce the same in their examination papers. It should not be so. Education must make the student think. It must make them invent new ideas and not reinvent the same wheel. There are teachers who enter classrooms and teach in the most uninspiring manner without an iota of a passion to change lives or to make education entertaining and interesting. They transform the most interesting subjects into disastrously painful experiences. Parents dream for their children and in order to fulfill these so-called dreams, they pressurize their children into a crazy race for more marks, a race which has never benefited anyone. 
Chetan Bhagat's Five Point Someone and the adapted films 3 Idiots and Nanban challenge the present trends in education, the narrow mindedness of teachers and parents in forcing the children to choose the profession which they consider suitable, keeping in view the prevailing perception in society regarding that profession. Moreover, the movies also criticize the glaring anomalies in the Indian education system which needs to be rectified. They highlight the challenges in our present education which emphasizes on rote learning and memory. 3 Idiots and Nanban are eye openers for parents, teachers and educational institutions to know the real pulse of students and act accordingly

Youngsters are moulded by their parents. Very often their attitude is changed depending upon their parents. While some parents provide maximum support and love towards their children, some fail to provide the right guidance and love. Conflicts occur between parents and teenagers because of misunderstanding, over protection, dominance, negligence and lack of communication. In this present age most parents themselves make choices for their children's higher education. They fail to consider their children's interest. The modern trend among people is to make their daughter a doctor, and son an engineer, which gives social prestige in society. Middle class Indian parents fear that their kids will lead a life of hardship if they don't get into engineering or medicine degree. A dialogue in the movies 3 Idiots and Nanban reveal this:

Mona: When you were talking, he kicked, first time.

Rancho: He? How do you know it is a he or she?

Mona: Papa asked the astrologer if we would get an engineer

or a doctor.

Rancho: Meaning?

Pia: Boy becomes an engineer, girl a doctor.

Rancho: champ, better stay inside, out here is a circus, your

grandpa is the ringmaster, He will crack his whip.

The pressure does not stop at being an engineer, but to add an MBA as that degree becomes part of an elusive group, although it's becoming too common now. This reference is captured in the movie where Rancho tells Pia: "Your boy friend is an ass. He first did his engineering and then did an MBA and now works in a bank. If he wanted to work in a bank then why did he choose to become an engineer."

Chetan Bhagat vividly portrays the realities in the life of youngsters in Five Point Someone: What not to do at IIT. He echoes the varied voices of the youth; their agonies, frustration, dilemma and expectations. In Five Point Someone Neha's brother Samir commits suicide because of his bullying father who forces him to join IIT while his own intension is to become a lawyer. As a result of his disinterest he fails to get into IIT. Prof. Cherian fails to understand his son's real interest and talents. Dominated by his father Samir remains voiceless and is not able to express his intention. This leads him to commit suicide. In his letter to his sister, Samir states: "I have tried three times to get into IIT and each time I have disappointed dad. He cannot get over the fact that his son cannot handle physics, chemistry and maths" (166).

The letter of Samir is also a kind of treatise which presents the hopes, expectations and aspirations of the parents in the materialistic age regarding their children. Even though Samir does not blame his father for suicide, anyone can understand his situation. Some part of the letter can again be quoted here

He has seen thousands of IIT students in his life and cannot see why his own son cannot make it. Well Neha, he sees the students who make it, but he does not see the hundreds of thousands who don't make it. He has not even talked to mom properly because of me. What can I do? Keep trying until I die? Or simply die?. (167)

Like Samir, hundreds of young people are agonized by parental pressure and some even go to extent of committing suicide. His letter may be treated as a severe criticism against the educational system of the country.

The writer is not only critical about the system of IIT entrance exam, but also of the grading systems in the technical exams. He admits the fact that the greatest minds are spoiled in their youth. It also makes them frustrated and cut off from the main stream.

Neha's character is a sensitive portrayal of what it is like to be young and female in an overprotective, patriarchal world. When Hari gains her trust, she falls in love with him and even goes to the extent of having physical relationship with Hari. Her father strictly insists on her avoiding boys but she meets Hari often. Prof. Cherian is also strict about her receiving phone calls from boys. Protection is needed to some extent but overprotection and restriction lead children naturally to move beyond their limit. But at the same time children fail to understand the reason behind their parent's conditions because of their immaturity.

In the films, Pia/Ria falls in love with Rancho/Pari, whom her father considers as his enemy. She endures everything at the beginning out of respect for his father, but at one point, Pia/Ria denounces her father in the same way that Rancho/Pari did over the suicide of Joy Lobo/Paneer Selvam. Pia/Ria tells Virus: 
I gave him (Rancho/Pari) the key dad I wish I would have given this to my brother, he would be alive today, you think your son fell off a train and died? You decide he would be an engineer, Did you ask him what he wanted to be? You put such pressure on him that he chose death over the entrance exam. He wanted to study literature, be a writer but all he wrote was this suicide note...It is a murder, not a suicide.

Lack of proper interaction and understanding between parents and children is the reason behind such problems and the suicides that ensue. The role of parents is very demanding.

Parents need to give up the concept that they can make their children do anything. Parents can inspire, teach, influence, lead, guide, motivate, stimulate, and encourage their children to positive, cooperative behavior...Power struggles can destroy a parent-child relationship. Power struggles can destroy a child's sense of self-worth and selfesteem. Power struggles can eventually escalate into the more serious stage of rebellion and revenge. (King "Helping to deal with power struggles")

Unlike Prof. Cherian there are certain parents who leave their children and go abroad. They work abroad to earn for their children. But they fail to realize that Children lack parental love. Though they give their children total freedom, lack of love makes them feel frustrated. Ryan becomes a victim of such predicament as his parents move abroad to earn. About Ryan the narrator says: "Ryan's father and mother were both intimately involved in the business and their travel meant Ryan stayed in boarding school..." (13). The only way they communicate to their son is through letters. But Ryan never replies them back because he never receives their love directly. His pain and hatred towards his parents who left him in the age of six and the reason he gives for his preference of friends is very touching. "Mom and dad are nice, but I don't love them the way I love my friends. I mean I don't love them, but I love my friends" (39).

Though Ryan's parents send him expensive gifts he never feels any affection towards them. In the modern era, either parents send children abroad to study or they themselves move abroad to work. This again breaks the parent- children bond. One learns and earns in order to live a happy life. Instead of living together when people live apart they miss love and happiness.

Separation from parents makes youngsters feel alienated. Though Ryan seems to be unconcerned about his love for his parents, within him there is a longing for love. This is evident when Alok speaks about Ryan:

But there is more to Ryan. Like did you know his parents send him a letter every other week? Or that he never replies to any of them? Yes he will tell you he doesn't love them or whatever crap he dishes out. But the truth is, he keeps every letter neatly in a file. When he is alone in his room at night he opens the letters and reads them again. (74)

In order to highlight parents' obsession with degrees for social status the character of Rancho is introduced in the movies. Rancho/Pari being an orphan is overpowered by his owner that is real Rancho's father. Rancho is a lazy wealthy child who dislikes studies. On the other hand Phunsukh Wangdu the gardener's son is interested in studies, and so Rancho makes him do all his assignments and homework. When they are caught, Rancho's father says: “This boy wants to study. I want just a degree, let the game go on. Make this kid an engineer and I will have a degree in my son's name on that wall". Hence the servant boy studies in Rancho's place instead of labouring, and the real Rancho pockets the qualifications and the benefits thereof.

Youngsters are frustrated when parents pressurize them to come up in life to help them economically. Coming from a very poor background Alok/Raju is always seen worrying about his studies and job. As his father is paralyzed he has to take up all the responsibilities of his family. The narrator states:

Alok's family, I guess, was of limited means, which is just a polite way of saying he was poor. His mother was the only earning member and last I heard, School teachers didn't exactly hit dirt on pay-day. Besides, half her salary regularly went to support her husband's medical treatment. At the same time, Alok's sister was getting near what he mournfully called 'marriageable age' another cause of major worry for his household. (13)

His mind is always preoccupied with the thought about his parents. In Five Point Someone it is because of his phone call to his mother from Prof. Cherian's office that the operation pendulum plan is broken and the three friends get caught red-handed. His family situation even moves him to break his friendship. He is so sensitive that when he hears about the Disco Committee plan to suspend them for one semester he becomes frightened and jumps from a building to commit suicide.

In the films, when Prof. Virus asks Raju/Senthil to choose between Rancho and himself to be expelled. In he jumps out of Virus's room-window and goes into a coma stage. He awakens from coma, only when 
Rancho/Pari lies that his sister's marriage is fixed. This shows how his mind is always preoccupied with the thought about his family. The youngsters face such emotional conflicts because of lack of good relationship with their parents. Family is a cultural institution in which the young boys become victims when all the responsibilities are dumped upon them.

In the films, Farhan/Venkat studies engineering to fulfill his father's wish by crushing his own dreams of becoming a wildlife photographer. His father has sacrificed so much to make him an engineer so Farhan/Venkat would not dare to say that he would prefer a zoom lens over a compass and divider set. Farhan/Venkat says: "I was born at 5.15 and 5.16 am my father said 'My son will be an engineer' ',

Farhan/Venkat's dreams distract his studies and so he scores low grades. Finally when he takes courage to speak the truth to his father understands his passion for photography and embraces his son's decision not to continue engineering. He is rewarded by the smile on his son's face. Finally Farhan/Venkat realizes that he is free from years of mental torture.

Every child is not as gifted as Latha Mangeshkar or Tendulkar, but most of them end up living their parents' dream at an engineering institution or a medical college. In the films Rancho/Pari says that "If Latha Mangeshkar's father had not permitted her to sing or Sachin Tendulkar was restricted from playing cricket what would they have been doing?" The films also show a student committing suicide which raises a pertinent question "Was it a suicide or murder?"

In the media reports, Rajkumar Hirani, the director revealed that he had tried hard to convince his father about his desire to pursue film-making. Therefore, according to him pursuing one's dream is very essential, backed with proper education.

According to Sri Sathya Sai Baba "Parents and teachers are the sculptors who have to mould the shape of the students for whom they are responsible. If parents and teachers set the right example, the students will automatically blossom into models of excellence and bring glory to the nation" ("Sai Baba of India- Sai Baba quotes on education"). A teacher paves way for a person to develop not only his intelligence but also his character. Most often teachers become the role model for many students. So teachers need to reflect the best part of their nature to their students.

With technological advancements, many technical institutions have emerged in India. Especially institutions like IIM, IIT are noteworthy. Five Point Someone brings to light a particular institution, IIT. But the incidents related to this institution reflect the other educational institutions as well. But the films make a mockery at the whole education system in India. The educational system gives more importance to marks than the creativity of students. Students are trained to mug up their lessons. Regarding this Ryan says "Boss, mugging is the price one pays to get the IIT tag. You mug, you pass and you get job...continues mugging, testing and assignments, where is the time to try new ideas?" (25). In the films, Rancho/Pari teaches everyone about the consequences of mugging, by changing the speech which is to be given by Chatur/Srivatsan, the mugger. Chatur/Srivatsan mindlessly memorises the speech without noticing anything that is amiss, partly aided by his lack of knowledge on Hindi. His speech becomes a laughing stock for the audience.

Education should be for the flowering of personality but not for the suppression of creativity or natural skills. But students are expected to copy the already existing pattern to make a screw-jack. When Ryan tries to make his own screw-jack, his professor scolds him. He always intends to make something new. In the movies, Joy Lobo/Paneer Selvam who is very creative creates a helicopter-cum-camera for his project. But Prof. Virus refuses to accept it, by saying that the project is something unrealistic. In this way students are not allowed to use their own creativity. Blaming the whole IIT system Ryan says: "This system of relative grading and overburdening the students. I mean it kills the best fun years of your life. But it kills something else. Where is the room for original thought? Where is the time for creativity? It is not fair" (35).

Regarding this, in the movies Rancho/Pari says, "Here they don't discuss new ideas or inventions, they discuss, jobs, grades, settling in the USA, they teach how to get good scores, they don't teach engineering". According to Edward de Bono "There is no doubt that creativity is the most important human resources of all. Without creativity, there would be no progress and we would be repeating the same patterns." Though Ryan/Pari scores less he has a great practical mind to do research. But it is he who remains jobless at last and acquires a position as assistant researcher with meager income.

No doubt that present educational system is making engineers, doctors, C.A and other officers. but there is lack of values. Our present educational system is not playing a significant role in shaping the future of our youth. Preparing the youth as the job seekers or job mongers with low value system they are 'literate' but not 'educated'. Most of the youth at present think that success means going abroad. Very few of the best brains like to stay on. (Sahni "Health of Educational Systems in India”) 
Those who excel in studies are attracted to jobs abroad. Some of the talented students of our country are sent by Indian institutions to work abroad. This situation is well expressed by Ryan's questions to his friends as to why India still remains more underdeveloped than other countries though it possesses intelligent engineers. With regard to IIT Ryan questions: "How many great engineers or scientists have come out of IIT?... over thirty years of IIT's, yet, all it does is train some bright kids to work in multinationals, I mean look at MIT in the USA" (34).

Our educational institutions have become centers of indiscipline and lawlessness because they impart that type of education to the students which rarely proves useful to the students in their later life. The result is that students themselves during the course of receiving education feel frustrated and have no creative interest in the lessons taught to them in the class rooms (Jasvir "Essay on Technical Education in India")

The reason for the students themselves to move abroad is to gain good salary which is revealed through Alok's way of moving abroad to work. This shows that required salary is not given in India for talented people. But there are certain people like Ryan who want to work for their own country though they get meager wages. Through such characters the author voices the voice of younger people who expect certain steps to be taken by the government to honour the talented youth of our country.

Both the novel and the movies revolve around the power-relationship between teacher and students. Education has been undergoing rapid changes in the last several years. However "the traditional view of education, a view that still prevents, holds that learners must submit themselves to teachers" (Menges 5). As Menges further suggests, this view means that the teachers' authority is not to be questioned. The underlying assumption is that without communication of power by the teacher over the student, the student cannot learn.

In the novel, when a professor asks the new students to define a machine and they fail to come up with an answer mentions, the Professor explains that a machine is "... anything that reduces human effort. Anything. So, see the world around you and it is full of machines" but the hero Ryan asks a brainy and pertinent question "Sir, what about a gym machine, like a bench press or something? That doesn't reduce human effort. In fact, it increases it" (10). The Professor does not know how to respond, but he gets angry, the conversation proceeds as follows

"What are you trying to do?" the professor asked tight lipped as he came close to us again "Are you saying I am wrong?"

No sir, I'm just...

'Watch it son. In my class, just watch it', was all Prof. Dubey said as he moved to the front. (11)

In the movies, the professor sounds unreasonably stupid by insisting on jargon. When Rancho/Pari makes him realize the worth of using simple language he sends him out of the class.

Again when another Professor Vohra asks the students to design a car jack to lift the chassis incase of flat tires, Ryan draws a modified screw-jack in which one does not have to open manually and raise the jack. A flat tire does not mean the engine has failed. Hence one can attach a motor on the traditional jack and hook it up to the car battery. If one switches on the car ignition, the motor car derives power. Ryan is very happy with the design. But the Professor finds it difficult to accept his original thinking and the conversation proceeds as follows:

"What is this?" Ryan said, twisting his head around to make

sense of Ryan's unfamiliar drawing.

"Sir, this is a modified screw-jack," Ryan said, "It can be

attached to the car's battery..."

"Is this an electrical engineering class?"

"No sir but the end need is the same..."

"Is this an internal combustion engines class?"

"Sir but..."

"If you don't want to be in my class or follow my course, you

may leave". (118)

In Five Point Someone Prof. Cherian is pictured as a cruel lecturer, who always considers students with five point GPA as a low grade, but never takes any steps to improve them. He even rejects the Lube project of Ryan without reading it. He cannot accept a student with low grade to do a project. He never appreciates the talents of Ryan. "A teacher who is attempting to teach, without inspiring the pupil with the desire to learn, is hammering on a cold iron" ("Horace Mann Quotes").

Power relationship is more effectively portrayed in the films through the character Prof. Viru Sahastrabudhhe, the director of the institution whose first lesson to students is 'compete or die'. Prof. Virus, the unsmiling Principal who venerates the cuckoo because the bird's life begins with murder, tells the youngsters to kill the competitors because there is only one place at the top, but he doesn't know that the competition is something stupid, in which the muggers like Chatur/Srivatsan end up as stereotypes in real life while the non-conformists like 
Rancho, who do not care about being on top, could end up as eventual winners. More importantly they could be high not only in intelligence quotient (IQ), but also in emotional quotient (EQ) never losing their humanness and social networking skills. He also doesn't realize that in real life the intention of IIT joiners are not to out throw his competitors. In India there is no sufficient infrastructure in educational setup to pool all the super brains. Most students fail in the IIT exams in point difference and one can't cull them as unfit just because of the cut off mark set for limited seats

In the films, Farhan/Venkat describes "Dr. Viru Sahastrabudhhe/Virumandi Santhanam was the director of ICE. Virus was the most competitive man we had ever seen. He could not bear anyone getting ahead of him. To save time, his shirts had Velcro and his ties had hooks, he trained his mind to write with both hands simultaneously..." He tells the students on their first day in college, "You will have to beat your competitor every step of the way if you want to be successful in life". When the other students follow his orders, Rancho/Pari defies his rules. He raises questions in class which his teachers cannot answer, refuses to complete assignments unless he really enjoys them and infuriates the dean who is a stickler for perfection. Rancho/Pari tells the Dean straight-faced, enraging him further: "You have the best colleges in the country, yet none of your students have ever invented of note".

To make matters worse, Rancho/Pari falls in love with his daughter. The Dean tries to make Rancho/Pari's life hell but however Rancho/Pari deceives him every time. He also attempts on a number of occasions to destroy Rancho's friendship with Farhan/Venkat and Raju/Senthil, warning them and their parents to get away from Rancho/ Pari. When Rancho/Pari continues to come first in every exam, his tension mounts. Even he threatens to expel Raju/Senthil lest he expels Rancho/Pari. Unable to choose between his friend and letting down his family, Raju/Senthil tries to commit suicide.

There is another character Joy Lobo/Paneer Selvam who commits suicide, because he requests Virus an extension on his major project on helicopter- cumcamera as he had to look after his father who suffers from stroke. But Virus refuses, saying that he himself is unmoved by his own son's accidental death after being hit by a train. The dialogue proceeds as follows:

Lobo/Selvam: Sir I am this close, sir.

Virus: Submit it and we will consider.

Lobo/Selvam: Sir a small extension.

Virus: Why, Why should I?

Lobo/Selvam: After dad's stroke, I couldn't

focus for two

months.

\author{
Virus: Did you stop eating? \\ Lobo/Selvam : No, Sir. \\ Virus: Stopped bathing? Mr. Lobo/Selvam \\ Sunday afternoon \\ my son fell off a train and died, Monday \\ morning I taught a \\ class, so don't give that nonsense... I can \\ give you sympathy \\ not an extension.
}

Suicides among youngsters has become very common mainly because of their unexpressed feelings and unbearable situations. The feeling of agitation and depression and the bullying by parents and teachers drive teenagers to kill themselves. The Times of India says: "Bullying or being bullied not only causes stress to teenagers, but it may even push them towards committing suicide, say researchers who conducted a review of studies from thirteen countries" ("Bullying can cause teens to commit suicide").

Alok/Raju attempts suicide because of his fears about his future. In the same way Neha/Pia/Ria's brother commits suicide as he is forced to join IIT though his actual interest is in another field. The decision of these youngsters shows how far these people are pressurized in different situations. Rancho/Pari imparts the seriousness of suicide by telling Virus: "Look at these statistics- India ranks number one in suicides, every ninety minutes a student attempts suicide. Suicide is a bigger killer than disease".

The youngsters who ought to be encouraged and developed to become successful, are tormented. Deprived of the opportunity to develop intellectually, many youngsters suffer from the problem of subjective isolation and self-estrangement. The feeling of hopelessness, helplessness and depression make the youngsters kill themselves.

Marriage, in its many forms has been a part of cultures for thousands of years. Marriage is a pivotal stage for anyone who is a part of the cultural system. Marriage better defined as the union of two families in India where only few people treat it as a union of two souls. Customs, ceremonies, formalities all differ from people, religion and economical status.

Indian parents who had gone through a hard life always look for the safety and status of their children. And they always prefer the match from same community, religion and of same status. It is quite similar in case of $\mathrm{Pia} / \mathrm{Ria}$. She is being engaged to Suhas, a wealthy man, while doing her first year medicine. This is not an example of union of two souls. Here social status and win-win situation of two families are considered by Pia/Ria's father Virus. But Rancho/Pari disapproves of her fiancé saying: "He is not a human, he is a price tag. 
He will turn your life into a nightmare of brands and prices...life for him is just a profit-loss statement, he sees profit in you, so he is with you, director's daughter, doctor in the making...,good for his image! It's not you he cares for".

Marriage is one of the most sacred and holy ceremonies in our society. But the horror of the dowry system has made this ceremony one of the feared institutions. In ancient Indian society there was no question of dowry in marriages. It was considered to be a sin. The bridegroom was voluntarily presented with useful gifts which were not demanded at all. In some cases bride's father was offered money to allow her to marry a young man, because the bride was considered to be virtuous and suitable to the groom. But now the whole situation is altered. Nobody bothers to approach a girl's parents for her marriage. The parents of the girl desperately move in search of a suitable groom for her. They persuade the groom's parents and tempt them with dowry. Through these unfair means they get the consent of the groom's parents for his marriage. Thus begins the clandestine atmosphere of dowry. The groom's parents continue to place a series of demands before the bride's parents. The demands include refrigerator, colour television, ornaments, money, plots of land etc., which differs in different societies.

Dowry is such an evil which spreading likes AIDS and cancer in our society though Government has strict laws against it but to no purpose. But it is duty of all enlightened citizens of our country to fight out this evil. We must rid our society of this curse. In this regard the youths of the society can be of great help. They should come forward and start a massive campaign for rejecting and socially boycotting the people accepting the dowry. If this is not done, serious consequences are likely to affect our society. (Chetan "514 Words Complete Essay on evils of dowry system")

Dowry system is an evil in Indian society. It reduces the dignity of both man and woman. Many educated men are demanding dowry. Thus dowry system is also an insult to our education and culture. Poor people cannot afford dowry, hence many poor girls remain unmarried. It is the case with Alok/Raju's sister. The groom's family demands a Maruthi 800 beside the dowry. They demand dowry to be given before the marriage. It is revealed in when Alok says: "They wanted a portion of the dowry right now. To lock in the boy. Mom said she will apply for a loan but it will take a few months. Meanwhile, they get another deal and it is all cver.
Bloody idiots..." (178). It is so common, that the greedy people demand dowry at once before the marriage.

The three idiots, Rancchoddas Shyamaldas Chanchad, Raju Rastogi and Farhan Qureshi are perfect archetypes of the new age Indian who is essentially a non-conformist, questioning outmoded givens, choosing to live life on his own terms and chartering new roads that consciously skirt the rat race. Of course, they begin on the beaten track -- due to societal/parental pressure -- but refuse to become cogs in the wheel. Naturally, they end up as the Frostian hero (Robert Frost's Road Not Taken) who made all the difference to his life, and the world, by taking the road less travelled by. ("3 Idiots movie review")

Modern youth aspire to create a society that is free from outmoded customs and irrational beliefs. They courageously and resolutely resist any force that is against them. While yearning to lead an independent life in order to reach their destination, they expect the elders to understand them and to give them good guidance. Bhagat and the directors have given voice to these desires through the novel and films.

\section{REFERENCES}

[1] Bhagat, Chetan. Five Point Someone: What not to do at IIT! New Delhi: Rupa. Co, 2004. Print.

[2] Blue Stone, George. Novels into Films. Baltimore: johns Hopkins Press, 1957. Print.

[3] Boyum, Joy Gould. Double Exposure: Fiction to Film. Calcutta: Seagull Books, 1985. Print.

[4] "Bullying can cause teens to commit suicide." timesofindia. N.p., 8 July 2008. Web. 4 Jan 2018.

[5] "Horace Mann Quotes-BrainyQuote." brainyquote. N.p., n.d. Web. 5 Jan. 2018.

[6] Jasvir. "Essay on Technical Education in India." preservearticles. N.p., 26 Mar. 2011. Web. 3 Jan. 2018.

[7] King, Shirley. "Helping to deal with power struggles- Parent News." parent.net. N.p., n.d. Web. 4 Jan 2018.

[8] Mohan, Indira Cultural Studies: an Extended Literary Domain. New Delhi: Atlantic Publishers, 2010. Print.

[9] Nanban. Dir. Shankar. Perf. Vijay, Jeeva and Shrikanth. Gemini Film Circuit, 2012. Film.

[10] Sahni, Ashok. "Health of Educational Systems in India" medind.nic. N.p., n.d. Web. 3 Jan. 2018.

[11]"3 Idiots movie review." timesofindia. N.p., 24 Dec. 2009. Web. 12 Feb. 2018. 